\title{
FIBER DISRUPTION OF BETUNG BAMBOO (D endrocalamus asper) BY COMBINED FUNGAL AND MICROWAVE PRETREATMENT
}

\author{
WIDYA FATRIASARI ${ }^{1}$, WASRIN SYAFII ${ }^{2}$, NYOMAN WISTARA ${ }^{2}$, KHASWAR SYAMSU $^{3}$, \\ BAMBANG PRASETYA ${ }^{4}$, S. HERIS ANITA ${ }^{1}$ and LUCKY RISANTO ${ }^{1}$ \\ ${ }^{1}$ Rescirch Cetter for Biomaterials Indonesian Institite of Säenes (LIPI), \\ Jalan Raya Boor Km46 Cikinong Bogr 16911, Indonesia \\ 2Department of Forest Produrt Techndogy, Faailty of Forestry, Insitut Petanian Bogr, \\ Bogor 16680, Indonesia \\ ${ }^{3}$ Departmet of AgoIndustrial Tedndogy, Faalty of Agiaultural Engineeingand Tedndogy, \\ Institut Petanian Bogr, Bogr 16680, Indonesia \\ ${ }^{4}$ National StandardizationAgengy, Mangggla Wanabakti BuildingBldk IV , $4^{\text {th }}$ Flor, \\ Jalan Gatct Subroto Senayan, Jakarta, Indonesia
}

Received 22 January 2014/ Accepted 3 D ecember 2015

\begin{abstract}
Combined fungal and microwave pretreatment is an attractive method to alter carbohydrate and lignin structure of lignocellulosic materials for improving hydrolysis process to convert these lignocellulosic materials to bioethanol. This study was conducted to obtain information on the carbohydrate and lignin characteristic changes after combined biological and microwave pretreatment of betung bamboo. Based on our previous research, incubation for 30 days using 5 and $10 \%(\mathrm{w} / \mathrm{v})$ inoculum loading of white rot fungi, Tramtes vesicdor which has better delignification selectivity compared to the other incubation time, was chosen as the fungal pretreatment prior to microwave pretreatment for 5,10 and 12.5 minutes at $330 \mathrm{~W}$. The evaluation of characteristic changes after pretreatment was performed using the analysis of FTIR spectroscopy, X-Ray diffraction and SEM. FTIR spectra demonstrated that the combined pretreatment only affected the change of intensity bands of FTIR spectra, without any changes in the functional groups. This band intensity decrease occurred on unconjugated bonds of carbohydrate peaked at $1,736 \mathrm{~cm}^{-1}$ ( $\mathrm{C}=0$ in xylan), $1,373 \mathrm{~cm}^{-1}$ (C-H deformation in cellulose and hemicellulose), $1,165 \mathrm{~cm}^{-1}$ (C-O-C vibration in cellulose and hemicellulose) and $895 \mathrm{~cm}^{-1}$ (C-H deformation or C-O-C stretching at $\beta$-glicosidic linkage characteristic in cellulose). The pretreatment decreased the hydrogen bond stretching of cellulose and the linkage between lignin and carbohydrate. This decrease of hydrogen bond was associated with crystallinity of bamboo cellulose, illustrated by occurring structural changes. The crystallinity index tended to increase slightly due to the cleavage of the amorphous fraction. SEM imagesillustrated that the pretreatment disrupted the fiber structure. The longer duration of microwave irradiation, thegreater the degradation level of fiber.
\end{abstract}

Keywords: betung bamboo, carbohydrate and lignin changes, combined biological and microwave pretreatment, FTIR, SEM, XRD

\section{INTRODUCTION}

Increasing concern of greenhouse gas emission and the depletion of fossil fuels have been considered as the main driving force in exploring renewable energy sources ( $\mathrm{Hu} \&$ Wen 2008; Zhang 2008). Abundant lignocellulosic materials are potential bioresources to produce liquid biofuel, such as bioethanol. However, the recalcitrance nature of biomass due to the

* Corresponding author : widya_fatriasari@yahoo.com presence of lignin and cellulose crystalline structure prevents optimum enzyme penetration during hydrolysis.

Effective pretreatment prior to hydrolysis stage is required to improve biomass digestibility. Pretreatments are emphasized mainly to increase feedstock surface area and porosity, as well as to reduce cellulose crystallinity, lignin content and hemicellulose content (Mosier Eal. 2005; G albe \& Zacchi 2007; Wyman \& al. 2007; Cara \&al. 2008). An effective pretreatment of biomass is indicated 
by sugar release improvement, reduced carbohydrate degradation and the lack of inhibitory by-products such as furfural, hydroxymethyl furfural (HMF) and organic acids formation (Kuhnel \& al. 2011; A gbor \& al. 2011) and also be cost-effective (Yang \& Wyman 2008; Agbor \&al. 2011).

Bamboos are versatile fast growing species of $\mathrm{C}_{4}$ plant type with very efficient photosynthesis ability. Theoretical value of $\mathrm{C}_{4}$ photosynthesis is approximately $8 \%$. Biomass productivity of bamboo is about 20-40 tonnes/ ha/ year. It is approximately 7-30\% higher than that of woody plants (K ant 2010) and other energy crops such as poplar, switch grass, miscanthus, common reed and bagasse (Sathitsuksanoh \& al. 2010; Zhang 2008). Bamboos are distributed in the tropics, subtropics and temperate zones (Lobovikov $\notin a \mathrm{al}$. 2007 ) and cover $1 \%$ of the world's forest area (Kant 2010). Most of bamboo population (65\%) grows in Asia, especially in Indonesia with 160 bamboo species (Widjaja 2001). This ranks third $(5 \%)$ in world bamboo's population after China (14\%) and India (30\%) (Lobovikov \& al. 2007). Betung bamboo is considered among the most important species in Indonesia (D ransfield \& Widjaja 1995). Previous study of six Indonesia's bamboo species demonstrated that fiber morphology, physical and chemical properties of betung bamboo were better than those of kuning, tali, andong, ampel and black bamboos (Fatriasari \& Hermiati 2008).

After single pretreatment, enzymatic hydrolysis in simultaneous saccharification and fermentation (SSF) can be applied to produce bioethanol. However, single pretreatment tends to produce low sugar yield, consume time and require high production cost due to enzyme requirement in saccharification process. Combined biological-microwave pretreatment could improve ethanol yield of biomass via SSF method. White-rot fungi used in biological pretreatment degrade lignin polymer by secreting ligninolytic enzyme (Zhang \&al. 2007; Nazarpour et al. 2013). An appropriate fungal strain is needed to obtain a satisfying delignification selectivity and enzymatic hydrolysis yield. D elignification selectivity of betung bamboo with Tramtesvesicdorwas found to be better than that with Plarrotus ostreatus and Phanerochaete drysosponium (Fatriasari \& al. 2011; Falah \& al. 2011). Microwave radiation of lignocellulosic material in aqueous environment is also found promising (Kheswani \& al. 2007). This pretreatment method has been applied for switch grass, bagasse, rice straw, woody plants, oil palm empty fruit bunch, oil palm trunk and frond (Hu \& Wen 2008; Keshwani 2007; Anita \& al. 2012; Risanto \& al. 2012; Lai \& Idris 2013). The advantages of the method include short processing time and high product yield and quality (Hermiati \& al. 2011). Microwave pretreatment supplies direct internal heat to biomass resulted from polar bond vibration as they align with the magnetic field (Kheswani \&al. 2007). Microwave pretreatment can increase ion production, solubilize non-polar material and hydrolyze biomass without catalyst (Tsubaki \& Azuma 2011).

In a study on biological and microwave pretreatment of betung bamboo, incubation for 30 days in biological pretreatment resulted in high lignin removal and less cellulose loss (Fatriasari \& al. 2014a). Furthermore, microwave pretreatment of biomass at $330 \mathrm{~W}$ for 5,10 and 12.5 minutes resulted in lowerweight loss of the a-cellulose and hemicellulose compared to that of other pretreatment conditions (Fatriasari $\&$ al. 2014b). To the best of our knowledge, no study has been reported on the changes of lignin and carbohydrate structure after combined biologicalmicrowave pretreatment. This study was conducted to obtain information on the carbohydrate and lignin characteristic changes after combined biological and microwave pretreatment of betung bamboo.

\section{MATERIALS AND METHODS}

\section{Material Preparation}

Betung bamboo (Dendrocalamus asper (Schult.f.)) of less than 2 years old was collected from bamboo plantation of the Research Center for Biomaterials LIPI, Cibinong, Indonesia. The bark of the collected bamboo was removed and the barkless bamboo was chipped before being ground into fine powder. The powder was sieved to obtain 40-60 mesh bamboo meal and then stored in a sealed plastic bag at room temperature. Betung bamboo meal was subjected to biological pretreatment before microwave irradiation. 


\section{Bamboo Sample Preparation}

Bamboo meal was watered with ratio of 1:4 and then manually stirred until completely mixed. The wet bamboo-meal was then put in a jar and steamed for 30 minutes at approximately $100{ }^{\circ} \mathrm{C}$ and finally sterilized in an autoclave for 20 minutes at $121^{\circ} \mathrm{C}$.

\section{Inoculum Stock Preparation}

T. versicdor fungus inoculum was cultured on Malt Extract Agar (MEA) slant (10.65 g of MEA were diluted in $300 \mathrm{~mL}$ distilled water) for 7-14 days. At the end of incubation period, $5 \mathrm{~mL}$ of JIS (Japan Industrial Standard) broth

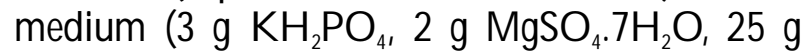
glucose, $5 \mathrm{~g}$ pepton and $10 \mathrm{~g}$ malt extract diluted into $1 \mathrm{~L}$ of distilled water) was injected to the slant and then scratched with loop to release the resulting mycelium from the slant agar. As much as $5 \mathrm{~mL}$ of previously prepared fungi suspension was then poured into the remaining $95 \mathrm{~mL}$ of the JIS Broth medium and stationery incubated at $27^{\circ} \mathrm{C}$ for 7-8 days. After incubation, $10 \mathrm{~g}$ of corn steep liquor was poured into the $100 \mathrm{~mL}$ inoculum and homogenized twice with a high speed Waring blender (each homogenization was conducted for 20 seconds).

\section{Inoculation Method}

Bamboo-meal (15 g oven-dried weight) having $7.46 \%$ moisture content was inoculated with 5 and $10 \%$ inoculum (w/v) of dried bamboo and incubated at $27^{\circ} \mathrm{C}$ for 30 days.

\section{Microwave Pretreatment}

Microwave pretreatment was carried out in an oven microwave SHARP P-360J (S) with $2,450 \mathrm{MHz}$ frequency and power output of 1,100 W. As much as $1 \mathrm{~g}$ of oven-dried pretreated sample was inserted into a Teflon tube (vessel), added with distilled water to obtain a solid-toliquid ratio (SLR) of 1:30 (w/v) and stirred for 15 minutes. Subsequently, the sample was exposed to microwave irradiation at $330 \mathrm{~W}$ for 5, 10 and 12.5 minutes. After microwaving, the pulp was removed from the oven and immediately put into iced water for 15-20 minutes to cool the pulp. The residue (solid fraction) was separated from the hydrolysate (liquid fraction) by filtration.

\section{The Changes of Content, Morphological, Cellulose and Lignin Characteristics}

\section{Chemical componet tdetemination}

Prior to determination of chemical component of control and pretreated bamboo, the moisture content of samples were measured following the procedures of TAPPI T12 os-75. Free extractive bamboo-meal was prepared with ethanol-benzene (1:2) extraction for chemical component analysis. Acid-insoluble lignin, acid soluble lignin, holocellulose, a-cellulose and ash content were determined in accordance with the TAPPI T13 os-54, TAPPI UM 250, TAPPI T9m-54, TAPPI T17m-55 and TAPPI T 15 os58 standards, respectively. The calculation of weight loss was done following the method of Pandey \& Pitman (2003), while selectivity value was calculated as the ratio of lignin loss to cellulose loss (Yu tal. 2009).

\section{Cellulosecrystallinityindex determination}

The crystallinity index was determined using diffraction intensity data of X-ray Diffraction (XRD) according to the formulation of Zhou \& al. (2005). Measurement was carried out with Shimadzu XRD-700 MaximaX series. NI radiation was filtered by $\mathrm{CuK}_{\alpha}$ at $0.15406 \mathrm{~nm}$ wave number. X-ray was operated at $40 \mathrm{kV}$ of voltage, $30 \mathrm{~mA}$ of electrical current and scanned 2 theta $\left(^{\circ}\right)$ of $10-40^{\circ}$ in $2^{\circ}$ per minute.

\section{Allomophicstructureof cellulose}

Z-D iscriminate function (Hult \&al. 2003) was used to differentiate allomorphic properties of cellulose crystalline structure. The function was built up by separating cellulose $\mathrm{I}_{\alpha}$ and $\mathrm{I}_{\beta}$ using $\mathrm{d}$ spaces obtained from $\mathrm{X}$-ray analysis, i.e. two equatorial d-spacing: 0.59-0.62 $\left(\mathrm{d}_{1}\right)$ and 0.52-0.55 $\mathrm{nm}\left(\mathrm{d}_{2}\right) . \quad \mathrm{Z}>0$ indicates bacteria algae type $\left(\mathrm{I}_{\alpha}\right.$, rich triclinic structure) and $\mathrm{z}<0$ indicates cotton and flax types (predominantly $I_{\beta}$ structure/ monoclinic).

\section{Crystallitesizeof callulose}

The crystallite size of cellulose was determined using diffraction pattern obtained from (101), (10-1), (002) and (040) lattice planes of bamboo (Z hao \&al. 2007).

\section{Morphdogical structureanalysis}

Morphological structure of pretreated bamboo was analyzed through SEM micrograph obtained by a JEOUL/EO SEM. Bamboo 
sample was installed in the sample holder (stub) using sputter canter and then scanned at $15 \mathrm{kV}$ with $10 \mathrm{~mm}$ of working distance with 750x and $10,000 x$ of magnification.

\section{Biodegradationpattem}

Biodegradation pattern was analyzed through Fourier Transform Infrared Spectrometry (FTIR) spectrograph. To obtain FTIR spectra, $4 \mathrm{mg}$ of bamboo-meal was embedded in $200 \mathrm{mg}$ of $\mathrm{KBr}$ (Potassium Bromide) spectroscopy grade and then pelletized at 5,000 psi. The diameter and thickness of the pellet were approximately $1.3 \mathrm{~cm}$ and $0.5 \mathrm{~cm}$, respectively. Infrared spectrum patterns (peak height and area) were analyzed by using FTIR ABB MB 3000. All of the spectra were recorded at a spectral resolution of $16 \mathrm{~cm}^{-1}$ with the accumulation of 5 scans per sample with absorption mode in the range of $4,000-500 \mathrm{~cm}^{-1}$. The characteristic of carbohydrates and lignin was analyzed based on the relative band intensity change referring to the method of Pandey (Pandey \& Pitman 2003). Peak height and area values of lignin associated bands were rationed compared to carbohydrate reference peaks at 1,$720 ; 1,366 ; 1,180$ and $879 \mathrm{~cm}^{-1}$ to provide relative changes in the composition of the structural components relative to each other determined using Horizon MB software.

\section{Statistical Analysis}

All experiments were performed in triplicate. Sample preparation for SEM, FTIR and XRD analyses has been conducted by manually mixing all triplicate treated and untreated samples. The pretreatment combination effects on chemical component changes and losses were analyzed by ANOVA (Analysis of Variance) using MINITAB release 13.2 software. Significant differences among treatment combinations were evaluated using Tukey's multiple range comparisons at $\mathrm{p}<$ 0.05 .

\section{RESULTS AND DISCUSSION}

\section{ChemicalContent of Pretreated Bamboo}

The chemical component composition change of pretreated bamboo is depicted in Figure 1 which shows that bamboo has high a-cellulose content. Cellulose is the main source of C-6 sugar convertible to ethanol. In this study, combined biological-microwave pretreatment was utilized to reduce lignin content. The pretreatment was expected to degrade lignin and hemicellulose. Removal of the C- 5 hemicellulose could increase sugar fermentation by Sacharamyes crevisiae considering that the C-5 sugar of hemicellulose cannot be efficiently fermented by theyeast.

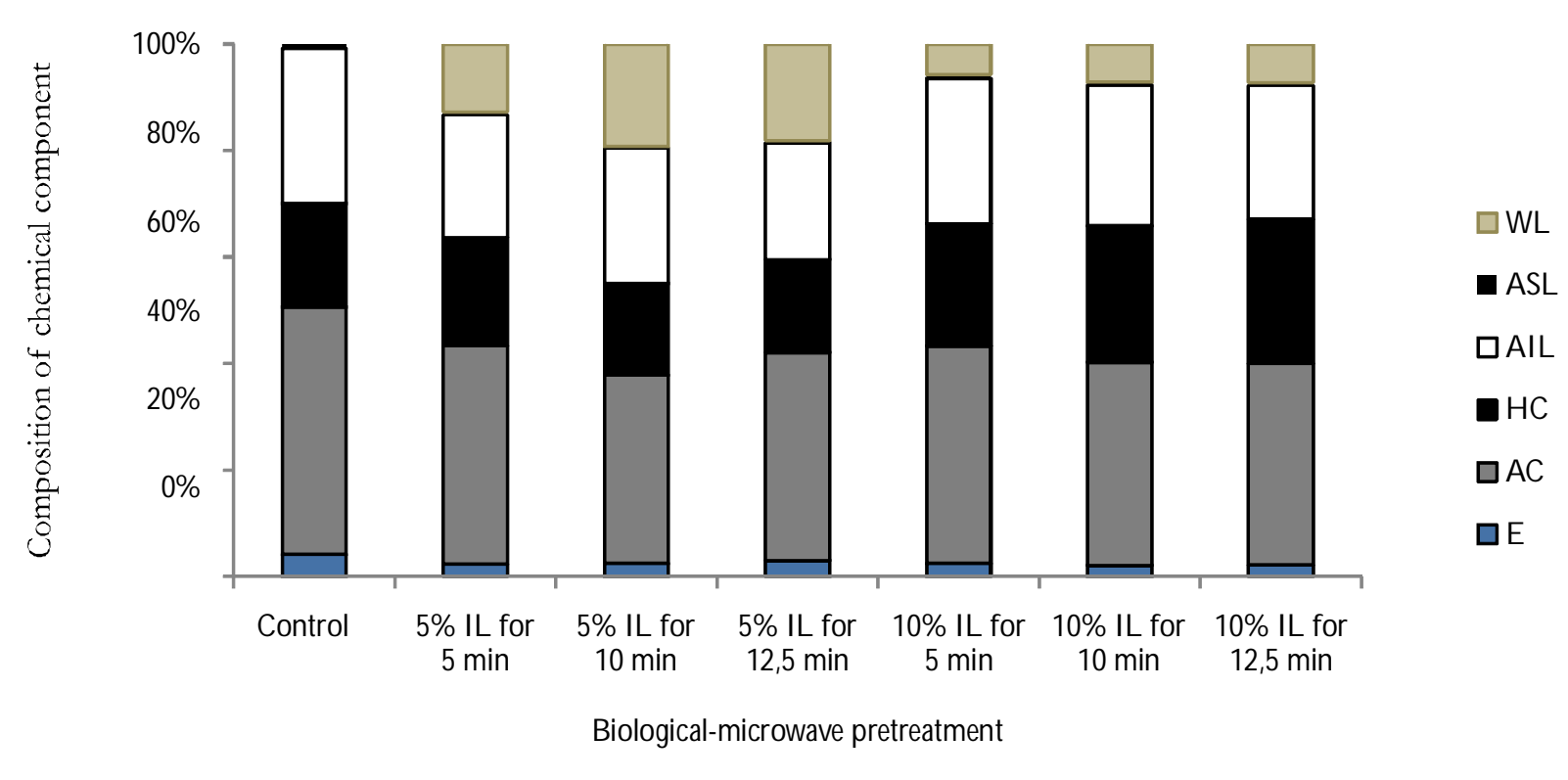

$\begin{array}{lllllll}\text { D S : } & 2.91 & 0.46 & 1.08 & 0.77 & 0.59 & 1.14\end{array}$

Figure 1 Chemical component composition change of bamboos after biological-microwave pretreatment. Components: IL (inoculum loading); WL (weight loss); ASL (acid soluble lignin); AIL (acid insoluble lignin); HC (hemicellulose); AC (alphacellulose); E (ethanol-benzene extractive); DS(delignification selectivity) 
The combined fungal-microwave pretreatment changed the chemical composition of pretreated bamboo (Fig. 1). Pretreatment of $10 \%$ inoculum loading showed lower weight loss or higher yield than that of $5 \%$ inoculum loading. Longer irradiation time tended to increase weight loss. This might be related to a more intensive lignin degradation activity than carbohydrate removal in higher inoculum loading. Total weight loss was approximately of 5.47-19.88\%. Statistical analysis indicated that only inoculum loading gave significant effect to alpha cellulose and hemicellulose content, weight loss and hemicellulose loss. On the other hand, only irradiation time gave significant effect on weight loss and lignin loss $(p<0.05)$. Based on Tukey's pairwise comparison, weight loss due to irradiation time were significantly different. Interaction between inoculum loading and irradition time significantly affected weight loss. However, no interaction effect between inoculum loading and irradition time on the alpha cellulose loss was found. Prolonging irradiation time for 10 minutes affected the decrease of apha cellulose loss for both inoculum loading. Even though, the irradiation time for 12.5 minutes caused higher lignin degradation, it also caused higher alpha cellulose loss. Thus, greater extend of irradiation time was not required.

The highest selectivity value (up to 2) was found after bamboo was pretreated with $5 \%$ inoculum loading and then was irradiated for 5 minutes. A higher selectivity value indicates that lignin polymer cleavage is more effective than cellulose degradation. Statistical analysis of the present results indicated that the inoculum loading and irradiation time did not significantly affect selectivity value $(\mathrm{p}<0.05)$.

D egradation of carbohydrate (alpha cellulose) also occurred during delignification activity (Fig. 1). It might be due to partial hydrogen bond disruption of the LCC (Lignin Carbohydrate Complex) (Li \&al. 2010). Biological pretreatment caused opening of the lignocellulose complex structure through depolymerization of lignin and brought about increasing carbohydrates accesibility. Microwave pretreatment after biological pretreatment also helped to alter the ultrastructure of cellulose and degrade lignin and hemicellulose in lignocellulosic materials that bring about increasing susceptibility of lignocellulosic materials (Binod $\notin$ al. 2012). Microwave heating transfers and induces heat directly into bamboo substrate, causing the depolymerization of sugar building block into oligosaccharides (E bringerova 2006).

Under acid pretreatment at high pressure and temperature, sugar monomer such as glucose and xylose can be further degraded in hydroxymethyl furfural and furfural (HMF) (Behera $\notin$ al. 2014). The degradation product can be released during acid pretreatment condition. More severe of microwave pretreatment condition led to decrease hemicellulosic monosaccarides in hydrolyzate and increase the formation of sugar degradation product (Kuhnel \&al. 2011). Various potential compounds in hydrolyzate consisted of acetic acid, formic acid, furan derivatives (5-HMF and furfural) and phenolic compounds might be generated. The inhibitor presence was not excepted due to the effect of limation efficient fermentation process (Zhang \&al. 2011; Talebnia \&al. 2010). However, due to our research focus was to observe the change of chemical component and cellulose structure of pretreated samples, this potential inhibitor on hydrolyzate was not observed.

\section{Cellulose Structure Changes of Pretreated Bamboo}

FTIR spectroscopy was used to investigate changes in the chemical structure of pretreated samples (Fig. 2 and 3). Slight changes occurred in spectrum peaks of biomass were treated with both 5 and $10 \%$ inoculum loading, but no changes appeared in the functional groups during pretreatment. It might becaused by uncompleted disruption of lignin that encapsulated cellulose. The broad absorption was observed at the wave number of around 3,340 $\mathrm{cm}^{-1}$. This wave number was assigned to hydrogen bond $(\mathrm{O}-\mathrm{H})$ stretching absorption. $\mathrm{O}-\mathrm{H}$ stretching region at the wave number of $3,000-3,600 \mathrm{~cm}^{-1}$ of pretreated bamboo spectra was more identical to the $\mathrm{O}-\mathrm{H}$ stretching region from cellulose I. The band at $2,700-2,901 \mathrm{~cm}^{-1}$ is related to the $\mathrm{C}-\mathrm{H}$ stretching (Pandey \& Pitman 2003). Biological-microwave pretreatment affected the peak area and bandheight of $3,340 \mathrm{~cm}^{-1}$ wave number $(\mathrm{O}-\mathrm{H}$ stretching) (Fig. 2 and 3). It indicated a weak intra and inter molecular bond of $\mathrm{O}-\mathrm{H}$ group (G oshadrou eal. 2011). 


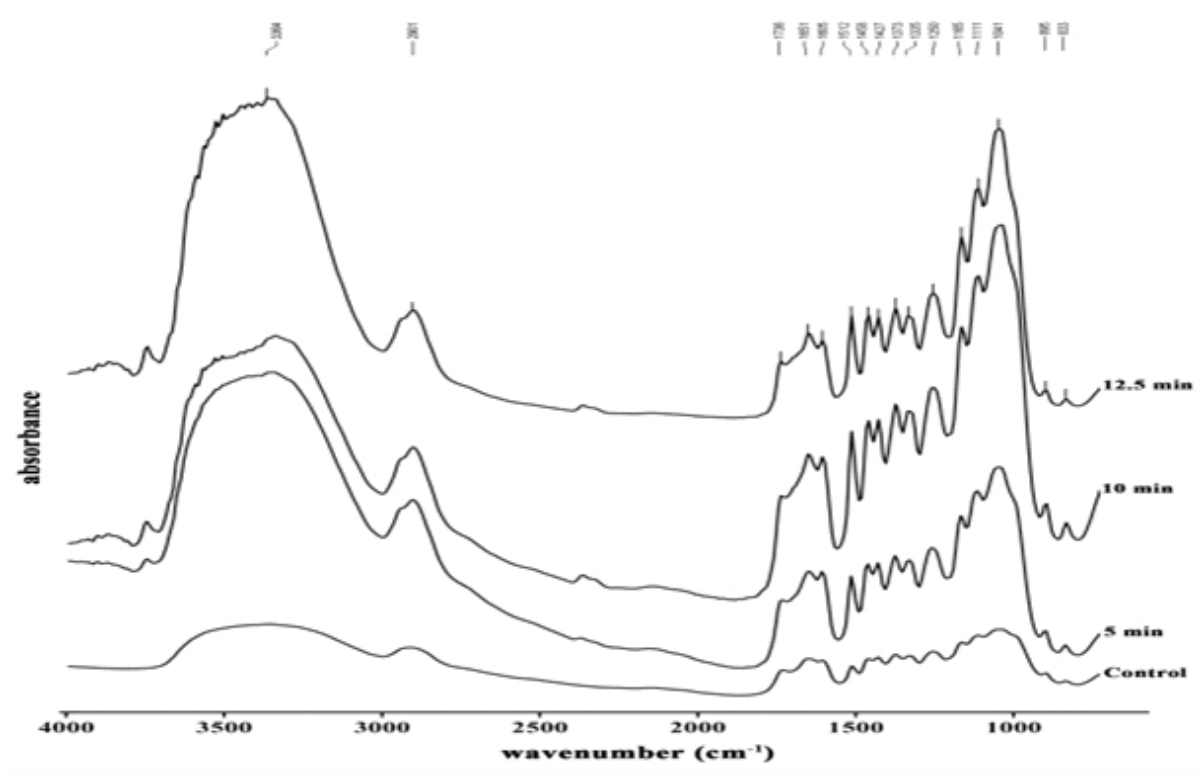

Figure2 FTIR spectra of bamboo after fungal pretreatment (5\% inoculum loading for 30 days) subjected to microwave pretreatment

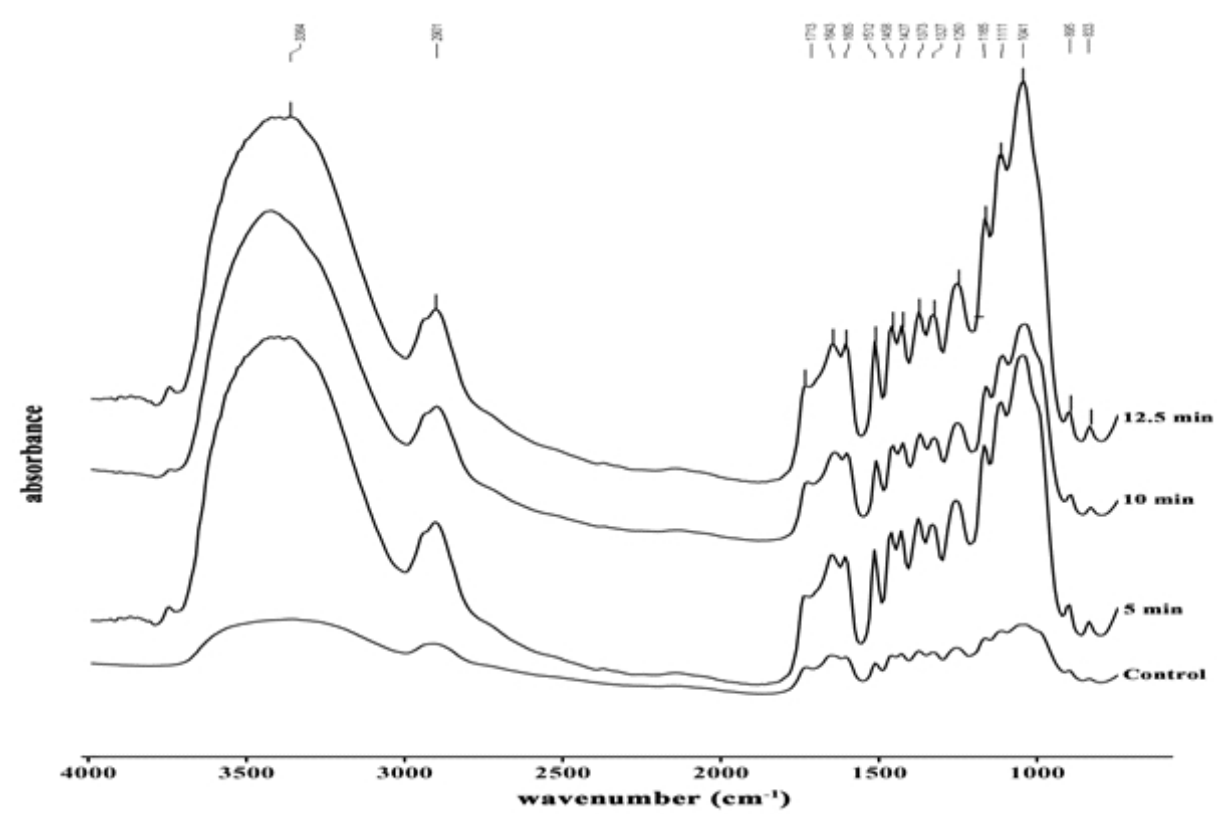

Figure 3 FTIR spectra of bamboo after fungal pretreatment (10\% inoculum loading for 30 days) subjected to microwave pretreatment

FTIR spectra with frequencies in the region of 1,600 and 1,510 (aromatic ring vibration), 1,470 and $1,460 \mathrm{~cm}^{-1}$ (C-H deformations and aromatic ring vibrations) can be found in the lignin structure (Fengel \& Wegener 1992). Lignin of bamboo consisting of $G$ uaiacyl $(G)$ and Syringyl (S) propane units containing one and two metoxyl groups can be clearly observed in all treatments at wave number of $1,327 \mathrm{~cm}^{-1}$ for Syringyl propane units and 1,257 $\mathrm{cm}^{-1}$ for G uaiacyl propane units. The higher absorbencies in the finger print of pretreatment of both 5 and $10 \%$ inoculum loading of pretreated samples compared to control was found at irradiation of 10 minutes. The higher lignin and cellulose content in this condition (Fig. 2) which can be confirmed by this spectra (Fig. 3). The absorbance of Syringyl $\left(1,327 \mathrm{~cm}^{-1}\right)$ was lower than that of Guaiacyl 
Table 1 Assignments of IR band of bamboo after biological-microwave pretreatment

\begin{tabular}{|c|c|c|c|c|c|c|c|c|}
\hline \multirow{5}{*}{ No } & \multirow{5}{*}{ Control* } & \multicolumn{6}{|c|}{ Biological pretreatment } & \multirow{5}{*}{ Assignments } \\
\hline & & \multicolumn{3}{|c|}{$\begin{array}{l}5 \% \text { of inoculum } \\
\text { loading }\end{array}$} & \multicolumn{3}{|c|}{$10 \%$ of inoculum loading } & \\
\hline & & \multicolumn{3}{|c|}{ Microwave } & \multicolumn{3}{|c|}{ pretreatment } & \\
\hline & & $\begin{array}{c}5 \\
\text { minutes } \\
\end{array}$ & $\begin{array}{c}10 \\
\text { minutes }\end{array}$ & $\begin{array}{c}12.5 \\
\text { minutes }\end{array}$ & $\begin{array}{c}5 \\
\text { minutes } \\
\end{array}$ & $\begin{array}{c}10 \\
\text { minutes }\end{array}$ & $\begin{array}{c}12.5 \\
\text { minutes }\end{array}$ & \\
\hline & & \multicolumn{6}{|c|}{ Wave number $\left(\mathrm{cm}^{-1}\right)$} & \\
\hline 1 & 3,394 & 3,340 & 3,333 & 3,418 & 3,418 & 3,425 & 3,364 & $\begin{array}{l}\text { A strong and broad hydrogen } \\
\text { bond }(\mathrm{O}-\mathrm{H}) \text { stretching absorption }{ }^{1}\end{array}$ \\
\hline 2 & 2,901 & 2,901 & 2,901 & 2,901 & 2,901 & 2,901 & 2,901 & $\begin{array}{l}\text { A prominent C-H stretching } \\
\text { absorption }^{1}\end{array}$ \\
\hline 3 & 1,736 & 1,728 & 1,736 & 1,736 & 1,728 & 1,728 & 1,713 & Unconjugated $\mathrm{C}=\mathrm{O}$ in xylans ${ }^{1}$ \\
\hline 4 & 1,643 & 1,643 & 1,651 & 1,651 & 1,643 & 1,643 & 1,643 & Absorbed $\mathrm{O}-\mathrm{H}$ and conjugated $\mathrm{C}-\mathrm{O}^{1}$ \\
\hline 5 & 1,605 & 1,605 & 1,605 & 1,605 & 1,605 & 1,605 & 1,605 & Aromatic skeletal ${ }^{1}$ \\
\hline 6 & 1,512 & 1,512 & 1,512 & 1,512 & 1,512 & 1,512 & 1,512 & Aromatic skeletal ${ }^{1}$ \\
\hline 7 & 1,458 & 1,458 & 1,458 & 1,458 & 1,458 & 1,458 & 1,458 & C-H deformation ${ }^{1}$ \\
\hline 8 & 1,427 & 1,427 & 1,427 & 1,427 & 1,427 & 1,427 & 1,427 & $\mathrm{C}-\mathrm{H}_{2}$ scissoring motion ${ }^{1}$ \\
\hline 9 & 1,373 & 1,373 & 1,373 & 1,373 & 1,373 & 1,373 & 1,373 & C-H deformation ${ }^{1}$ \\
\hline 10 & 1,335 & 1,327 & 1,335 & 1,335 & 1,327 & 1,327 & 1,327 & $\begin{array}{l}\text { C-H vibration }{ }^{1} \\
\text { C1-O vibration in syringyl } \\
\text { derivates }^{1}\end{array}$ \\
\hline 11 & 1,257 & 1,257 & 1,257 & 1,250 & 1,257 & 1,257 & 1,250 & Guaiacyl ring ${ }^{1}$ \\
\hline 12 & 1,165 & 1,165 & 1,165 & 1,165 & 1,165 & 1,165 & 1,165 & $\begin{array}{l}\text { C-O stretch } \\
\text { C-O-C vibration }\end{array}$ \\
\hline 13 & 1,111 & 1,111 & 1,111 & 1,111 & 1,111 & 1,111 & 1,111 & Aromatic skeletal and C-O stretch ${ }^{1}$ \\
\hline 14 & 1,049 & 1,041 & 1,034 & 1,041 & 1,041 & 1,041 & 1,041 & $\begin{array}{l}\text { C-O stretch }{ }^{1} \\
\text { C-O-C stretching at } \beta \text {-glicosidic }\end{array}$ \\
\hline 15 & 895 & 895 & 895 & 895 & 895 & 895 & 895 & $\begin{array}{l}\text { Linkage or C-H deformation in } \\
\text { Cellulose }^{2}\end{array}$ \\
\hline 16 & 833 & 833 & 833 & 833 & 833 & 833 & 833 & $\mathrm{C}-\mathrm{H}$ vibration ${ }^{3}$ \\
\hline
\end{tabular}

Notes: Control* $=$ D ata has been used in other paper (Fatriasari $\notin a$ al. 2014b)

$1=$ Pandey and Pitman (2003)

$2=$ Chen $\notin a l . ~(2011)$

$3=$ Cheng $\notin a l .(2013)$

$\left(1,257 \mathrm{~cm}^{-1}\right)$ indicating a higher Syringyl content in control and treatments. The typical infrared band frequencies and FTIR spectras of bamboo components in units of wavenumbers arelisted in Table1.

The sharp bands around $895 \mathrm{~cm}^{-1}$ is attributed to $\beta$-glicosidic linkage between the sugar units in cellulose (Nelson \& O'Connor 1964) which can be clearly seen in all spectra. The increasing microwave irradiation reduced band intensity of functional group ( $\mathrm{C}=\mathrm{O}$ ) in hemicellulose (3), $\mathrm{C}-\mathrm{H}$ in cellulose and hemicellulose (9), and C-O-C in hemicellulose (12). It might be attributed to the decrease of hemicellulose content after pretreatment along with lignin. Sixty functional groups can be observed in six pretreatment conditions. Each identified functional group can be found in all treatments, although a slight shift in wave number occurred. The treatments decreased functional groups intensity without changing functional group types.

\section{Effect of Combined Fungal and Microwave Pretreatment on Bamboo Morphology}

SEM micrograph of pretreated samples (Fig. 4 and 5) was used to observe morphological features and surface characteristics of pretreated bamboo with increasing microwaveirradiation. 


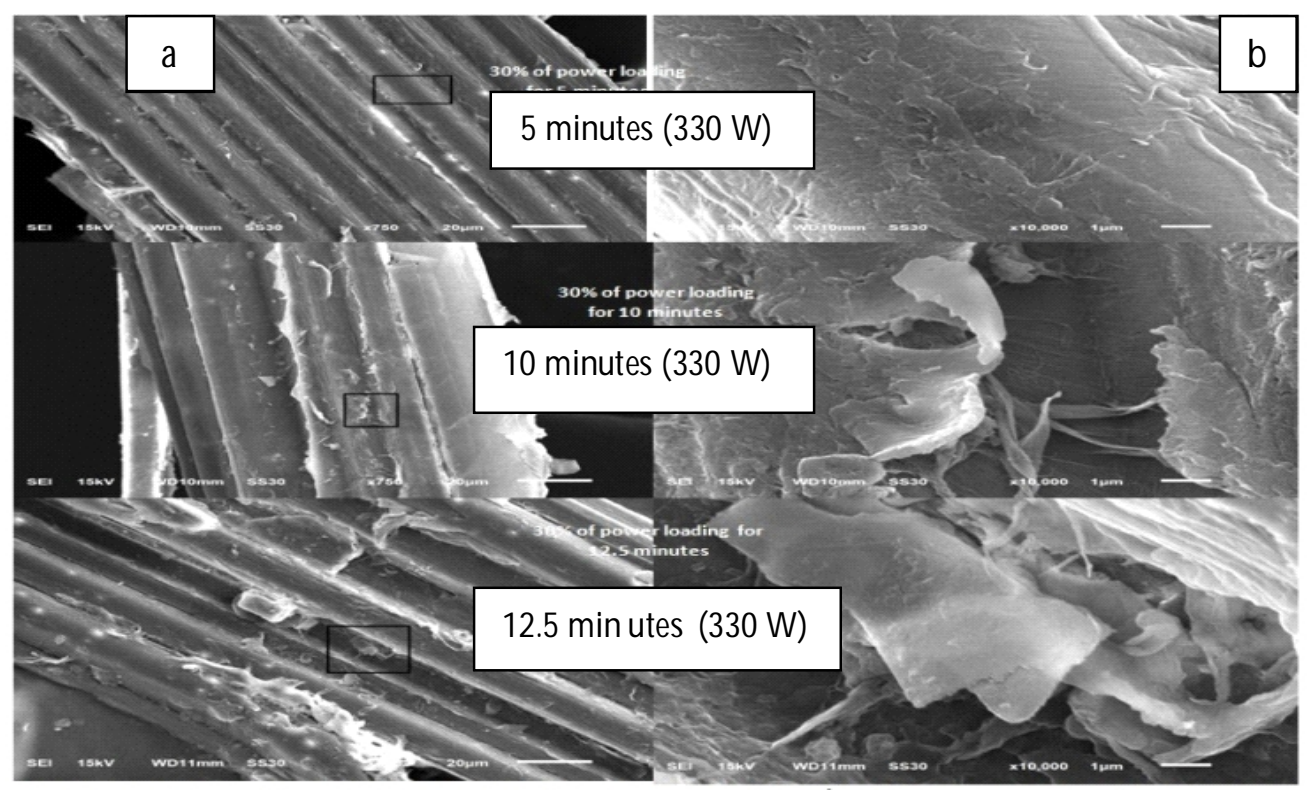

Figure 4 SEM micrograph of pretreated bamboo (5\% inoculum loading for 30 days) subjected to microwave pretreatment with (a) $750 x$ and (b) 10,000x magnification

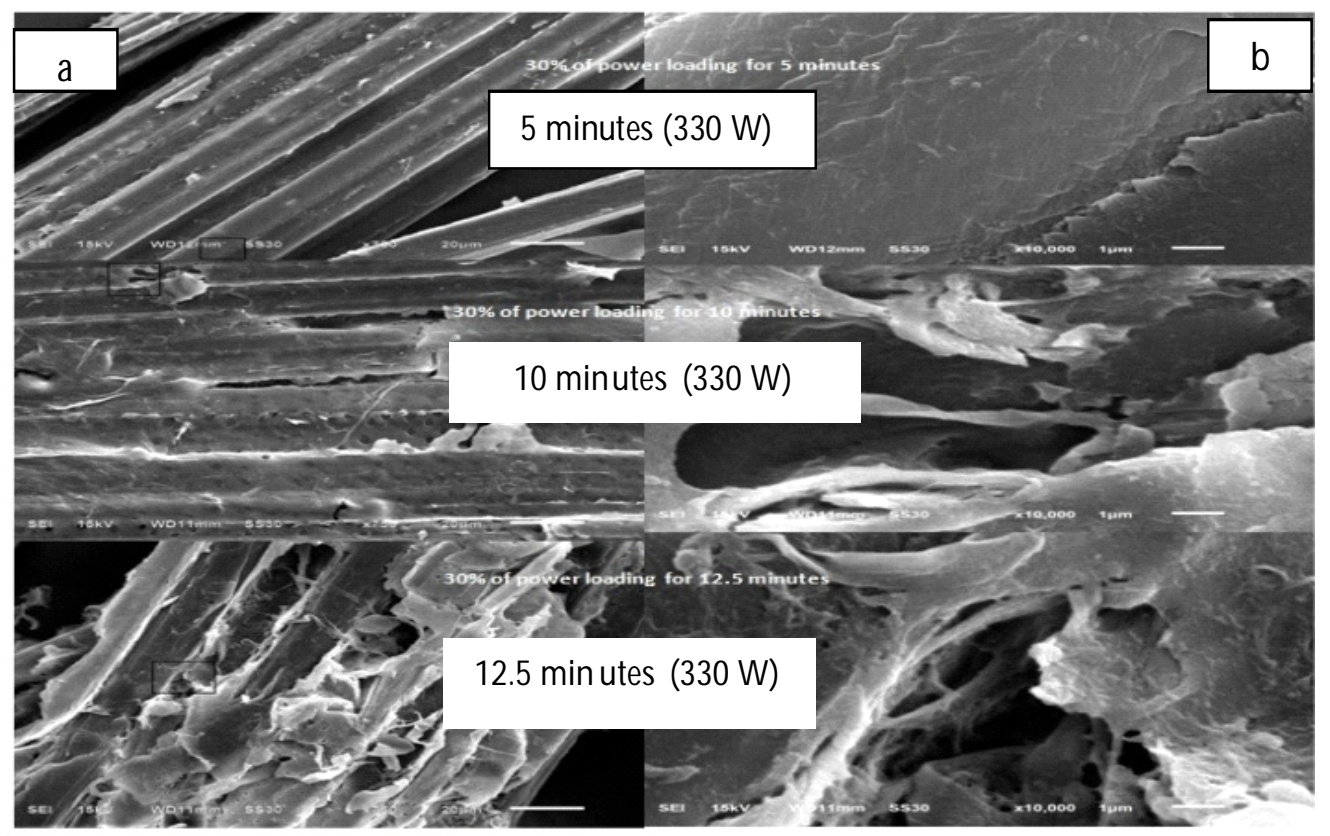

Figure 5 SEM micrograph of pretreated bamboo (10\% inoculum loading for 30 days) subjected to microwave pretreatment with (a) 750x and (b) 10,000x magnification

SEM images of samples treated with both 5 and $10 \%$ inoculum loading show that partial disruption occurred on the fiber structure. Degraded lignin polymer and removal of hemicellulose in cell wall might be responsible to this disorganized morphology. Longer microwave irradiation caused greater fiber degradation level. The cell wall morphology changes caused by lignin removal resulted in greater deconstruction of fiber surface, providing better cellulose penetration. Partial degradation of lignin and hemicellulose destroyed some ether bonds in lignin and lignin-carbohydrate complex leading to the disruption of the hydrogen bond between cellulose, thus fibrillation occurred (Li \&al. 2010). The cellulose digestibility can be potentially enhanced by preferential cleavage of lignin (Nazarpour $\notin$ al. 2013). Treatments of $5 \%$ 
Table 2 Crystalline allomorph of pretreated bamboo

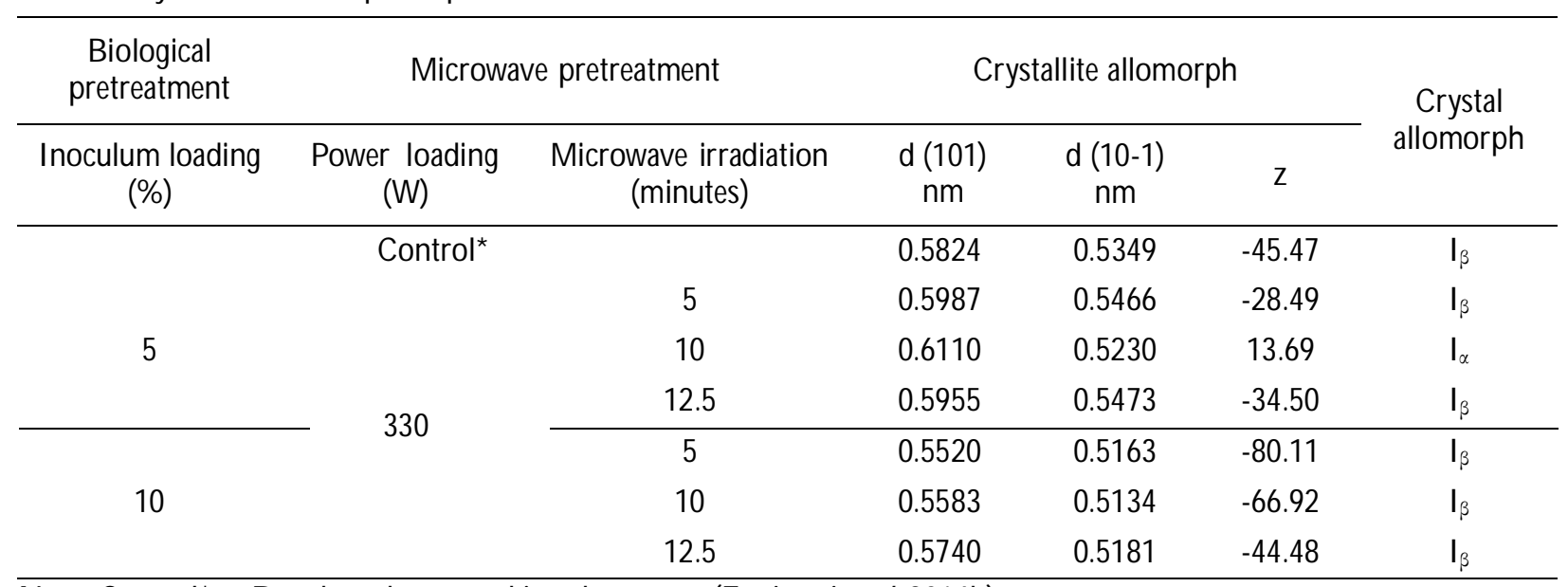

Note: Control* $=$ D ata have been used in other paper (Fatriasari $\notin a \mathrm{l}$. 2014b)

inoculum loading for 10 and 12.5 minutes microwave irradiation resulted in more openedup sponge-like structures providing wider surface area to increase the rate of subsequent hydrolysis reactions.

\section{Cellulose Structure Allomorph}

Crystalline allomorph of pretreated bamboo as a result of mixing triplicate samples observed by XRD is presented in Table 2. In general, cellulose consists of $\mathrm{I}_{\alpha}$ (one-chain triclinic) and $\mathrm{I}_{\beta}$ (two-chain monoclinic cells), which can be determined by $\mathrm{Z}$-discriminant. $\mathrm{Z}<0$ and $\mathrm{Z}>0$ indicate the $\mathrm{I}_{\beta}$ and $\mathrm{I}_{\alpha}$ allomorph types, respectively. Monoclinic $\left(\mathrm{I}_{\beta}\right)$ cellulose is more stable than triclinic $\left(\mathrm{I}_{\alpha}\right)$, and tends to be the final product in annealing treatment of all celluloses (Credou \& Barthelot2014).
All treatments except for the $5 \%$ inoculum loading for 10 minutes had monoclinic structure. However, the cause of this phenomenon has not yet been understood. The presence of the $\mathrm{I}_{\alpha}$ phase was expected to improve cellulose digestibility due to its higher degradation than that of $\mathrm{I}_{\beta}$. In addition, this structure is meta-stable and more reactive than $I_{\beta}$ (Moon etal. 2011).

\section{Biodegradation Pattern of Combined Biological-microwave Pretreatment}

Biodegradation patterns of bamboo during combined biological-microwave pretreatment were evaluated by FTIR analysis (Figure 6 and 7). A detailed FTIR spectroscopic analysis based on Pandey's analysis method was performed to calculate relative intensities of aromatic skeletal vibration against typical bands of carbohydrate on pretreated bamboo (Pandey \& Pitman 2003).

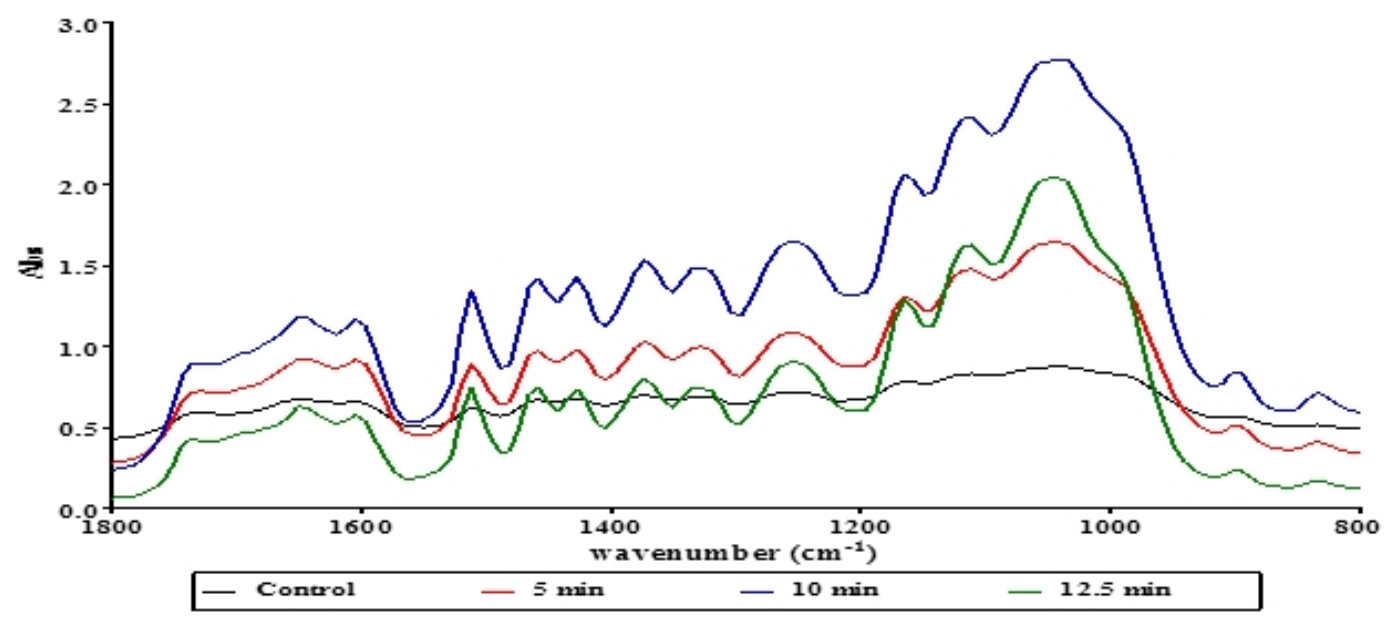

Figure 6 FTIR spectra of bamboo after biological pretreatment ( $5 \%$ inoculum loading for 30 days) subjected to microwave pretreatment (1) $1,736 \mathrm{~cm}^{-1}$, (2) $1,512 \mathrm{~cm}^{-1}$, (3) $1,373 \mathrm{~cm}^{-1}$, (4) $1,165 \mathrm{~cm}^{-1}$ and (5) $897 \mathrm{~cm}^{-1}$ 


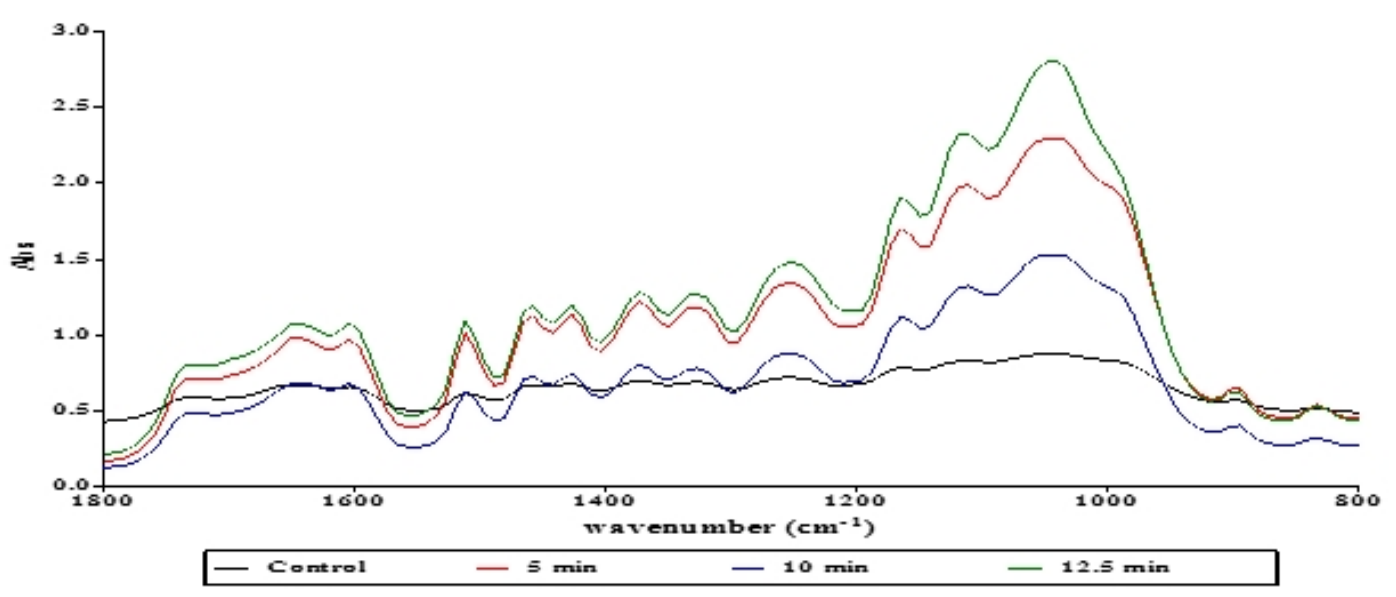

Figure 7 FTIR spectra of bamboo after biological pretreatment (10\% inoculum loading for 30 days) subjected to microwave pretreatment (1) $1,736 \mathrm{~cm}^{-1}$, (2) $1,512 \mathrm{~cm}^{-1}$, (3) $1,373 \mathrm{~cm}^{-1}$, (4) $1,165 \mathrm{~cm}^{-1}$ and (5) $897 \mathrm{~cm}^{-1}$

Relative changes in the intensities of aromatic skeletal in lignin peaks at $1,512 \mathrm{~cm}^{-1}$ against four unconjugated bonds of carbohydrate peaks at $1,736 \mathrm{~cm}^{-1} \quad\left(\mathrm{C}=\mathrm{O}\right.$ in xylan), $1,373 \mathrm{~cm}^{-1} \quad(\mathrm{C}-\mathrm{H}$ deformation in cellulose and hemicellulose), 1,165 $\mathrm{cm}^{-1}$ (C-O-C vibration in cellulose and hemicellulose), $895 \mathrm{~cm}^{-1}$ (C-H deformation or C$\mathrm{O}-\mathrm{C}$ stretching at $\beta$-glicosidic linkage characteristics in cellulose) calculated by peak heights and areas are summarized in Table 3.

In $5 \%$ inoculum loading, increasing microwave irradiation period tended to increase the ratio of lignin/ carbohydrate. It indicated that prolonged microwave irradiation decreased its lignin degrading ability of pretreated bamboo. Carbohydrate degradation after pretreatment contributed to this phenomenon.

\section{Crystallinity Index (CI) and Crystallite Size of Cellulose}

Crystalline and amorphous structure of cellulose can be identified from primary peak of XRD pattern ranging from $22-23^{\circ}$ and secondary peak in the range of $16-18^{0}$ (Lai \& Idris 2013; Liu \& al. 2012). These peaks can be determined within the mentioned range for all treatments, which indicates that the crystalline and amorphous region of cellulose. The crystallinity index of pretreated bamboo has been used to interpret changes of cellulose after pretreatment (Table 4). Intensity transformation in hydrogen bonding of cellulose can be reflected from width variation of crystallization peak.

Table 3 Ratio of intensity of lignin-associated band with carbohydrate bands of pretreated bamboo

\begin{tabular}{|c|c|c|c|c|c|c|}
\hline \multirow{3}{*}{$\begin{array}{c}\begin{array}{c}\text { Biological } \\
\text { pretreatment }\end{array} \\
\begin{array}{c}\text { Inoculum } \\
\text { loading (\%) }\end{array}\end{array}$} & \multicolumn{2}{|c|}{ Microwave pretreatment } & \multicolumn{4}{|c|}{$\begin{array}{l}\text { Relative intensities of aromatic skeletal vibration }\left(\mathrm{I}_{1,512}\right) \\
\text { againts typical bands for carbohydrates }\end{array}$} \\
\hline & \multirow{2}{*}{$\begin{array}{l}\text { Power loading } \\
\text { (W) }\end{array}$} & \multirow{2}{*}{$\begin{array}{l}\text { Irradiation time } \\
\quad \text { (minutes) }\end{array}$} & & & & \\
\hline & & & $\mathrm{I}_{1,512} / \mathrm{I}_{1,736}$ & $\mathrm{I}_{1,512} / \mathrm{I}_{1,373}$ & $\mathrm{I}_{1,512} / \mathrm{I}_{1,165}$ & $\mathrm{I}_{1,512} / \mathrm{I}_{897}$ \\
\hline & Control* & & 1.04(1.06) & $1.02(1.06)$ & $0.98(0.95)$ & $1.28(1.29)$ \\
\hline \multirow{3}{*}{5} & \multirow{6}{*}{30} & 5 & $1.24(0.83)$ & $0.86(0.6)$ & $0.67(0.33)$ & 1.74(3.75) \\
\hline & & 10 & $1.49(1.19)$ & $0.88(0.57)$ & $0.64(0.34)$ & $1.59(3.57)$ \\
\hline & & 12.5 & $1.74(1.88)$ & $0.94(0.81)$ & $0.58(0.48)$ & $3.26(2.5)$ \\
\hline \multirow{3}{*}{10} & & 5 & $1.42(1.37)$ & $0.83(0.74)$ & $0.59(0.48)$ & $1.55(1.51)$ \\
\hline & & 10 & $1.28(0.75)$ & $0.78(0.48)$ & $0.56(0.29)$ & $1.58(4.0)$ \\
\hline & & 12.5 & $1.36(1.33)$ & $0.84(0.77)$ & $0.57(0.47)$ & $1.73(1.69)$ \\
\hline
\end{tabular}

Note: Control ${ }^{*}=$ D ata have been used in other paper (Fatriasari \&al. 2014b) 
Fiber disruption of betung bamboo (Dendrocalamsaspe) by combined fungal and microwave pretreatment - Fatriasari \&al.

Table 4 Crystallinity Index (CI) and Lateral Order Index (LO I) of pretreated bamboo

\begin{tabular}{|c|c|c|c|c|c|c|c|c|}
\hline \multirow{3}{*}{$\begin{array}{c}\begin{array}{c}\text { Biological } \\
\text { pretreatment }\end{array} \\
\begin{array}{c}\text { Inoculum } \\
\text { loading } \\
(\%)\end{array}\end{array}$} & \multicolumn{2}{|c|}{ Microwave pretreatment } & \multirow{2}{*}{\multicolumn{3}{|c|}{$\begin{array}{l}\text { Crystallinity Index } \\
\text { (CI) }\end{array}$}} & \multirow{2}{*}{\multicolumn{3}{|c|}{$\begin{array}{l}\text { Lateral O rder Index } \\
\text { (LOI) }\end{array}$}} \\
\hline & \multirow{2}{*}{$\begin{array}{l}\text { Power } \\
\text { loading } \\
\text { (W) }\end{array}$} & \multirow{2}{*}{$\begin{array}{c}\text { Irradiation } \\
\text { time } \\
\text { (minutes) }\end{array}$} & & & & & & \\
\hline & & & $\begin{array}{c}\text { Fc } \\
\text { (Crystaline) }\end{array}$ & $\begin{array}{c}\text { Fa } \\
\text { (Amorf) }\end{array}$ & CI & $\begin{array}{c}\mathrm{A}_{1,427} \\
\text { (Crystalline) }\end{array}$ & $\begin{array}{c}\mathrm{A}_{897} \\
\text { (Amorf) }\end{array}$ & LOI \\
\hline \multirow{4}{*}{5} & \multirow[t]{2}{*}{ Control* } & & 0.69 & 2.13 & 24.58 & 0.50 & 0.40 & 1.25 \\
\hline & & 5 & 0.99 & 1.48 & 40.19 & 0.98 & 0.51 & 1.92 \\
\hline & \multirow{3}{*}{330} & 10 & 1.23 & 1.72 & 41.76 & 1.43 & 0.84 & 1.70 \\
\hline & & 12.5 & 1.12 & 1.54 & 42.04 & 0.74 & 0.23 & 3.22 \\
\hline \multirow{3}{*}{10} & & 5 & 1.16 & 1.74 & 39.98 & 1.14 & 0.65 & 1.75 \\
\hline & & 10 & 1.13 & 1.63 & 40.96 & 0.75 & 0.40 & 1.88 \\
\hline & & 12.5 & 0.93 & 1.34 & 40.84 & 1.20 & 0.63 & 1.91 \\
\hline
\end{tabular}

Note: Control* = D ata have been used in other paper (Fatriasari \& al. 2014b)

The crystallinity index tended to rise along with the increasing microwave irradiation. In biomass, cellulose contains crystalline area, while lignin and hemicellulose are amorphous in nature (O'Dowyer \& al. 2007). The increasing of crystallinity index might be caused by solubilization of amorphous component from the fibers under pretreatment condition $(\mathrm{Kim} \&$ Holtzapple 2006). This phenomenon was supported by the occurring component loss in lignin as presented in Figure 1. The increase of crystallinity index after pretreatment was also described in previous research (Singh $\&$ al. 2014; Bak eal. 2009).

Crystallinity index of cellulose is among the most important properties of lignocelluloses that can be measured by FTIR spectroscopy. Crystallinity index changes can be studied from LOI (Lateral Order Index), defined as the absorbance ratio of $\mathrm{A}_{1,427}$ to $\mathrm{A}_{895}(\mathrm{Oh}$ \&al. 2005), obtained from FTIR spectra data. Increasing of microwave irradiation time tended to increase LO I. It might be attributed to higher amorphous region of cellulose compared to crystalline region. This phenomenon was in line with crystallinity index measured by X RD analysis.

Crystallite size of cellulose in bamboo varied at lattice planes of (101), (10-1) and (002). The crystallite size ranged from 5.19 to 10.68 (Table5). The highest crystallite size of cellulose at (002) lattice plane was found in pretreatment of $5 \%$ inoculum loading for 12.5 minutes. Crystallite size at lattice planes (101) and (10-1) of several pretreated bamboos can not be calculated because there were no value of Full Width at Half Maximum (FWHM) in this peak. The microwave irradiation duration increaed crytallite size at (002) lattice plane. The highest crystalline length

Table 5 Crystallite size of pretreated bamboo

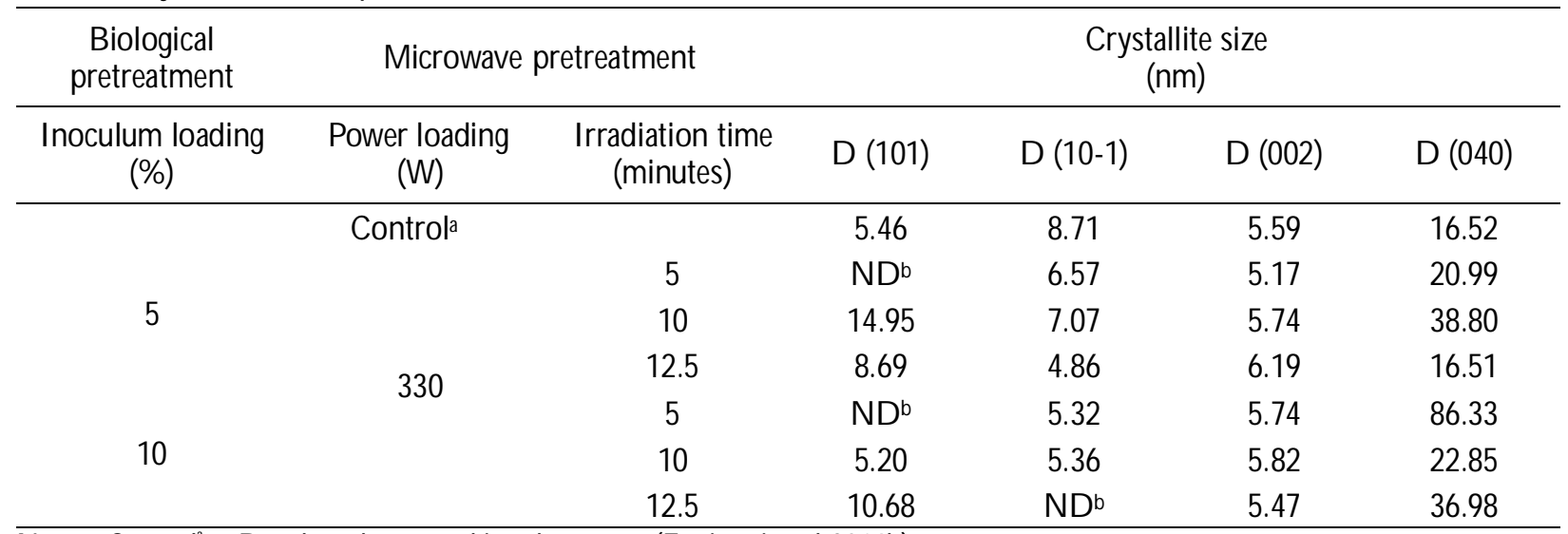

Notes: Control $^{\mathrm{a}}=\mathrm{D}$ ata have been used in other paper (Fatriasari $\notin a \mathrm{l}$. 2014b)

${ }^{\mathrm{b}}=$ not detected 
at (040) lattice plane of cellulose was found in the $10 \%$ inoculum loading for 5 minutes. There was no similar trend in crystalline length changes caused by increasing of microwave irradiation between 5 and $10 \%$ of inoculum loading.

\section{CONCLUSIONS}

The characteristic changes of lignin and carbohydrate of betung bamboo with combined biological-microwave pretreatment was evaluated. The pretreatment caused the loss of the chemical component. The $5 \%$ inoculum loading irradiated for 5 minutes demonstrated the highest selectivity value (up to 2). Based on FTIR spectra, there was no change in functional groups after pretreatment. Moreover, FTIR spectra also demonstrated the presence of hydrogen bond stretching along with microwave irradiation exposure indicating the structural changes occurred after pretreatment. The cleavage of the amorphous component contributed to the increasing crystallinity index. Disruption of fiber structure due to pretreatments was confirmed by SEM, in which the longer duration of microwave irradiation, the greater the degradation level of fiber.

\section{ACKNOWLEDGEMENTS}

The authors would like to thank SEAMEO BIOTROP for providing financial support as part of $\mathrm{PhD}$ thesis of the first author through D IPA 2013. Moreover, the authors expressed their gratitude to D wi H. Restuningsih, ST and Raden Budi L.Permana for their support in financial report and technical assistance.

\section{REFERENCES}

Agbor VB, Cicek N, Sparling R, Berlin A, Levin D B. 2011. Biomass pretreatment: fundamentals toward application. BiotechnolAdv 29:675-85.

Anita SH, Risanto L, Hermiati E, Fatriasari W. 2012. Pretreatment of Oil Palm Empty Fruit Bunch (OPEFB) using microwave irradiation. In: The $3^{\text {rd }}$ International Symposium of IWORS (Indonesia Wood Research Society). Proceedings: 2015 November 3-November 4; Yogyakarta (ID): Indonesian Wood Research Society. p348-54.
Bak JS, Ko JK, Han YH, Lee BC, Choi IG, Kim KH. 2009. Improved enzymatic hydrolysis yield of rice straw using electron beam irradiation pretreatment. BioresourceTechnol 100 (3):1285-90.

Behera S, Arora R, Nandhagopai N, Kumar S. 2014. Importance of chemical pretreatment for bioconversion of lignocellulosic biomass. Renew Sust EnergRev 36: 91-106.

Binod P, Satyanagalakshmi K, Sindhu R, Janu KU, Sukumaran RK, Pandey A. 2012. Short duration microwave assisted pretreatment enhances the enzymatic saccharification and fermentable sugar yield from sugarcane bagasse. Renew Energ 37(1): 109-16.

Cara C, Ruiz E, Miguel OJ, Saez F, Castro E. 2008. Conversion of olive tree biomass into fermentable sugars by dilute acid pretreatment and enzymatic saccarification. Bioresource Technol 99: 1869-76.

Chen W, Tu Y, Sheen H. 2011. Disruption of sugarcane bagasse lignocellulo sic structure by means of dilute sulfuric acid pretreatment with microwave-assisted heating. Appl Energ 88(8): 2726-34.

Cheng D, Jiang S, Zhang Q. 2013. Effect of hydrothermal treatment with different aqueous solutions on the mold resistance of Moso bamboo with chemical and FTIR analysis. BioResources. 8(1):371-382.

Credou J, Berthelot T. 2014. Cellulose: from biocompatible to bioactive material. J Mater Chem B Royal Soc Chemistry England 2: 4767-88.

D ransfield S, Widjaja EA. 1995. PlantResarresof SauthEast Asia No.7: BamboosLeiden (NL):Backhuys Publishers.

Ebringerova A. 2006. Structural diversity and application potential of hemicellulose. Macromo Symp 232: 1-12.

Falah F, Fatriasari W, Ermawar RA, Nugroho DTA, Hermiati E. 2011. Effect of corn steep liquor on bamboo biochemical pulping using Phanewhade drysosporium JITK T 9(2): 111-12.

Fatriasari W, Ermawar RA, Falah F, Yanto DHY, Adi DTN, Anita SH, Hermiati E. 2011. Kraft and soda pulping of white rot pretreated betung bamboo. JITKT 9(1): 42-55.

Fatriasari W, Hermiati E. 2008. Analisis morfologi serat dan sifat fisis-kimia pada enam jenis bambu sebagai bahan baku pulp dan kertas.JITHH 1(2): 67-72.

Fatriasari W, Syafii W, Wistara N, Syamsu K, Prasetya B. 2014a. Characteristic changes of betung bamboo (Dendrocalamus asper) pretreated by fungal pretreatment. IJRED 3(2): 133-43.

Fatriasari W, Syafii W, Wistara N, Syamsu K, Prasetya B. 2014b. Lignin and cellulose changes of betung bamboo (Dendrocalamus asper) pretreated by microwave heating. Trans Tech in Adv Material Research, in press. 
Fengel D, Wegener G. 1992. WoodChemistry, Ultrastructure, Reacions Walter de Gruyter \& Co: Berlin \& New York.

Galbe M, Zacchi G. 2007. Pretreatment of lignocellulosic materials for efficient bioethanol production. Adv Biochem EngBiotechnol 108: 41-65.

Goshadrou A, Karimi K, Taherzadeh MJ. 2011. Improvement of sweet sorghum bagasse hydrolysis by alkali and acidic pretreatment. In : Wood Renewable Energy Congress. Proceedings: 2011 May 8-May 13; Linkoping(SE). p 374-80.

Hermiati E, Azuma J, Mangunwidjaja D, Sunarti TC, Suparno O, Prasetya B. 2011. Hydrolysis of carbohydrates in cassava pulp and tapioca flour under microwave irradiation. Indo J Chem 11(3): 238-45.

Hu Z, Wen Z. 2008. Enhancing enzymatic digestibility of switchgrass by microwave-assisted alkali pretreatment. Biochem EngJ 38(3): 369-78.

Hult E-I, Iversen T, Sugiyama J. 2003. Characterization of the supermolecular structure of cellulose in wood pulp fibres. Cellulose 10: 103-10.

Kant P. 2010. Should banboos and palms be induded in CDM forestryprgiets?. Institute of G reen Econo my working paperno.IGREC-07:2010. IG REC.

Kheswani DR, Cheng JJ, Joseph CB, Li L, Chiang V. 2007. Microwave pretreatment of switchgrass to enhance enzymatic hydrolysis. ASABE Annual International Meeting, Minneapolis, Minnesota,17-20June2007.

Kim S, Holtzapple MT. 2006. Effect of structural features on enzyme digestibility of corn stover. Bioresource Technol 97(4): 583-91.

Kuhnel S, Schols HA, Gruppen H. 2011. Aiming for the complete utlization of sugar-beet pulp:Examination of the effects of mild acid and hydrothermal pretreatment followed by enzimatic digestion. Biotechnol Biofuels 4:1-14.

Lai LW, Idris A. 2013. Disruption of oil palm trunks and fronds by microwave-alkali pretreatment. BioResources 8(2):2792-804.

LiX, Ximenes E, Kim Y, Slininger M, Meilan R, Ladisch M, Chapple C. 2010. Lignin monomer composition affects Arabidopsiscell-wall degradability after liquid hot water pretreatment. Bictechnd Biduds3: 27.

Liu JG, Wang Q H, Wang DXS, Zou D, Sonomoto K. 2012. Utilization of microwave- $\mathrm{NaOH}$ pretreatment technology to improve performance and L-lactic acid yield from vinasse. Biosyst Eng 112: 6-13.

Lobovikov M, Paudel S, Piazza M, Ren H, Wu J. 2007. World Bamboo Resources. A Thematic Study Prepared in the Framework of the Global Forest Resources Assessment 2005.Non Wood Forest Products 18. Food and Agricultural Organization of the United Nations, Rome. p.73.
Moon RJ, Martini A, Nairn J, Simonsen J, Youngblood J. 2011. Cellulose nanomaterials review: structure, properties and nanocomposites. Chem Soc Re. 40: 3941-94.

Mosier N, Wyman C, D ale B, Elander R, HoltzappleYYLM, Ladisch M. 2005. Features of promising technologies for pretreatment of lignocellulosic biomass. Bioresource Technol96:673-86.

Nazarpour F, Abdullah DK, Abdullah N, Zamiri R. 2013. Evaluation of biological pretreatment of rubberwood with white rot fungi for enzymatic hydrolysis. Materials 6:2059-73.

Nelson ML, O'Connor. 1964. Relation of certain infrared bands to cellulose crystallinity and crystal lattice type. Part I. Spectra of lattice types I, II, III and of amorphous cellulose.J Poly SC 8 (3): 1311-24.

O 'D owyer JP, Zhu L, Granda CB, Holtzapple MT. 2007. Enzymatic hydrolysis of lime-pretreated corn stover and investigation of the $\mathrm{HCH}-1$ model: inhibition pattern, degree of inhibition, validity of simplified HCH-1 Model. Bioresource Technol 98(16): 2969-77.

Oh SY, Yoo DI, Shin Y, Seo G. FTIR analysis of cellulose treated with sodium hydroxide and carbon dioxide. Carbohydr Res 340 (3): 417-28.

Pandey KK, Pitman AJ. 2003. FTIR studies of the changes in wood chemistry flowing decay by brown-rot and white-rot fungi. Int Biodeter Biodegr 52: 151-60.

Risanto L, Anita SH, Hermiati E, Falah F. 2012. Microwave irradiation and enzymatic hydrolysis of sengon (Paraserianthes falcataria). In: The $3^{\text {rd }}$ International Symposium of IWORS (Indonesia Wood Research Society). Proceedings: 2015 November 3November 4; Yogyakarta(ID): Indonesian Wood Research Society. p 355-61.

Sathitsuksanoh, Zhu Z, Ho T-Jen, Bai M-D er, Zhang YiHeng P. 2010. Bamboo saccarification through cellulose solvent-based biomass pretreatment followed by enzymatic hydrolysis at ultra-low cellulose loadings. Bioresource Technol 101: 492629.

Singh R, Tiwari S, Srivastava M, Shukla A. 2014. Microwave-assisted alkali pretreatment of rice straw for enhancing enzymatic digestibility. J Energy: 1-7.

Talebnia F, Karakashev D, Angelidaki I. 2010. Production of bioethanol from wheat straw: an overview on pretreatment, hydrolysis and fermentation. BioresourceTechnol 101:4744-53.

Tsubaki, S, Azuma J. 2011. Application microwave technology for utilization of recalcitrant biomass. In: Grundas S, editor. Advances in Introduction and Miconave Heating of Mineal and Orgaric Materials Vienna (AT): In Tech Education and Publishing. P 697-722. 
Widjaja EA. 2011. Idanikit JenisJenis Bambu di Jana. Bogor (ID ): LIPI Puslitbang Biologi.

Wyman CE. 2007. What is (and is not) vital to advancing cellulosic ethanol. Trends Biotechnol 25(4): 153-7.

Yang B, Wyman CE. 2008. Pretreatment: the key to unlocking low-cost cellulosic ethanol. Biofuel Bioprod Bior 2: 26-40

Yu H, Guo G, Zhang X, Yan K, Xu C. 2009. The effect of biological pretreatment with the selective white-rot fungus Edhinodontiumtaxodi on enzymatic hydrolysis of softwoods and hardwoods. BicresarceTechm 100: 51705.

Zhang K, Agrawal M, Harper J, Chen R , Koros WJ. 2011. Removal of the fermentation inhibitor, furfural, using activated carbon in cellulosic-ethanol production. Ind Eng Chem Res 50 (24): 14055-60.

Zhang X, Xu C, Wang H. 2007. Pretreatment of bamboo residues with Condusversicdorfor enzymatic hydrolysis.J Biosci Biong 104(2): 149-51.

Zhang YHP. 2008. Reviving the carbohydrate economy via multi-product biorefineries. J Ind Microbiol Biotechnol 5:367-75.

Zhao H, Kwak JH, Zhang C, Brown HM, Arey BW, Holladay JE. 2007. Studying cellulose fiber structure by SEM, XRD, NMR and acid hydrolysis. Carbohyd Poly 68: 235-41.

Zhou D, Zhang L, Guo S. 2005. Mechanisms of lead biosorption on cellulose/ chitin beads. Water Res 39 (16):3755-62. 